\section{Uncertainty of Claims Provisions from the Analysis of Financial Statements}

\author{
Incerteza das Provisões de Sinistros a partir da Análise das Demonstrações \\ Contábeis
}

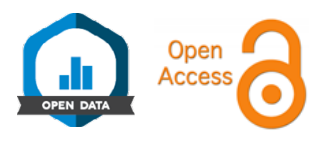

Roberto Bomgiovani Cazzari*1 0 Guilherme R. Fernandes Moreira ${ }^{1} \odot$

\section{ABSTRACT}

Objective: considering the current level of transparency in the financial statements of Brazilian insurers, this study sought to assess whether it was possible to estimate the sufficiency of the claims reserves estimated by it. As they are liabilities with an uncertain term or amount, the estimates of these reserves may be underestimated (compromising the insurers) or overestimated (burdening the shareholders), which justifies the research question. Methods: after analyzing the financial statements of 31 insurance companies in Brazil, it was noted that the criteria for disclosing claims development varied substantially. Thus, five insurers were selected that adopted similar procedures and allowed the application of the bootstrapping model to estimate the sufficiency level of the provisions. Results: the application of the model revealed that there are indications that insurers can make use of earnings management through the estimations of the claims reserves, spreading the burden of claims insufficiency risk differently between policyholders and shareholders. Conclusion: there are differences in the relative amount of claims recognized by the insurers, showing a possible earnings management practice being applied through the claims measurement.

Keywords: claims reserves; sufficiency; solvency; disclosure.

\section{RESUMO}

Objetivo: tendo em vista o nível de transparência atual das demonstraçôes financeiras de seguradoras brasileiras, este trabalho buscou avaliar se era possível estimar a suficiência das provisóes técnicas de sinistros por ela estimadas. Por serem passivos de prazo ou montante incertos, as estimativas de provisóes podem estar subestimadas (comprometendo as seguradoras) ou superestimadas (onerando os sócios), o que justifica a questáo de pesquisa. Métodos: após a análise das demonstrações financeiras de 31 seguradoras no Brasil, notou-se que os critérios de divulgação de desenvolvimento de sinistros variavam substancialmente. Assim, foram selecionadas cinco seguradoras que adotaram procedimentos similares e permitiram a aplicaçáo do modelo de bootstrapping para a estimação do nível de suficiência das provisóes. Resultados: a aplicação do modelo em tela revelou que há indícios de que as seguradoras podem fazer uso do gerenciamento de resultados por meio da estimaçáo de provisóes técnicas de sinistros, repartindo o ônus do risco de insuficiência das provisóes de forma diferente entre segurados e acionistas. Conclusáo: há diferenças nos níveis relativos de provisóes de sinistros reconhecidos pelas seguradoras, demonstrando que há um possível gerenciamento de resultados sendo aplicado por meio de sua estimaçáo.

Palavras-chave: provisôes de sinistros; suficiência; disclosure.

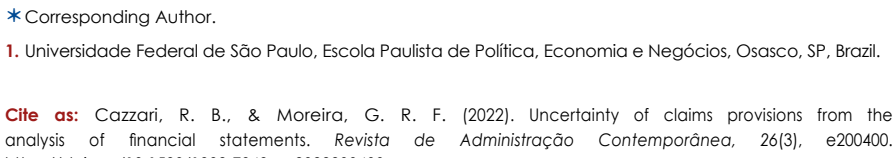

1. Universidade Federal de São Paulo, Escola Paulista de Políitica, Economia e Negócios, Osasco, SP, Brazil.

Cite as: Cazzari, R. B., \& Moreira, G. R. F. (2022). Uncertainty of claims provisions from the analysis of financial statements. Revista de Administração Contemporânea, 26(3), e200400. https://doi.org/10.1590/1982-7849rac2022200400.en

Published as Early Access: November 08, 2021 Assigned to this issue: December 10, 2021
JEL Code: $M 4$

Editors-in-chief: Wesley Mendes-da-Silva (Fundação Getulio Vargas, EAESP, Brazil) (1) Marcelo de Souza Bispo (Universidade Federal da Paraiba, PPGA, Brazil) Guest Editors: João Vinícius de França Carvalho (Universidade de São Paulo, FEA, Brazil) Eduardo Flores (Universidade de São Paulo, FEA, Brazill) Emiliano A. Valdez (University of Connecticut, USA) Reviewers: The reviewers did not authorize the disclosure of their identities. Peer Review Report: The disclosure of the Peer Review Report was not authorized by its reviewers.

Received: November 30, 2020 Last version received: July 23, 2021 Accepted: July 27, 2021

1 32434




\section{INTRODUCTION}

As financial products that contribute to society through risk sharing and for playing a key role in developing economies, the financial health of insurers is of greater importance for the economy of a country. If the costs and expenses of an insurance company are not well sized and it does not have sufficient resources to pay for its insured claims, the insurer may become insolvent and cause enormous damage to society. Unlike other industries, the insurers only know the total cost of claims after a long period. Depending on which insurance product is sold and the claims event, the final cost of a claim could linger for days, months, or even decades to be known (Friedland, 2010).

Due to uncertainties in terms of claims settlement and the amount that will be paid for each claim, insurers must maintain claims reserves. From an accounting point of view and following the guidance of the International Accounting Standards (IAS) in the publication IAS 37 - Provisions, Contingent Liabilities and Contingent Assets, the Comitê de Pronunciamentos Contábeis (CPC), through CPC 25, defines 'provisions' as "liabilities of uncertain timing or value" (Comitê de Pronunciamentos Contábeis [CPC], 2009, p. 4, our translation). The same standard defines 'liability' as "the entity's present obligation, derived from events that have already occurred, whose settlement is expected to result in an outflow of resources from the entity capable of generating economic benefits" (CPC, 2009, p. 5, our translation). Thus, given a certain accounting data, an insurer must dispose assets for the payment of all claims that occurred until this date, even if the insurer has not been notified of the claims (Mano \& Ferreira, 2009).

In this context, technical provisions are often the most representative item on the liability side of an insurer's balance sheet, as they represent the estimates that insurers must maintain to meet the obligations inherent in the insurance activity. To verify the importance of their numbers, only in 2019, according to data from the Superintendência de Seguros Privados (Susep), the provisions totaled $\mathrm{R} \$ 1,084,199,731,882$, representing approximately $14.84 \%$ of the Brazilian GDP.

In this sense, the correct dimensioning of provisions is essential to ensure the liquidity and solvency of insurance companies, which requires that they be well estimated. Therefore, the financial result of these companies is directly linked to the estimated value of the provisions. Thus, if there is an oversizing of these, the distribution of profits to shareholders may be compromised, reducing the investor's attractiveness and financial return. If technical provisions are undersized, the company will distribute undue profits and will not have guarantees to honor its commitments, and may become insolvent (Mano \& Ferreira, 2009).

The problems generated by undersized technical provisions do not end with the insurer and its clients. They affect the entire market, as if an insurer becomes insolvent, the credibility of the entire industry will be affected, creating insecurity, and diminishing customer confidence in products based on 'risk.' In this way, it is observed the great responsibility of companies in the correct dimensioning of technical provisions, extending from the insurance company to society (Mano \& Ferreira, 2009). Nevertheless, the estimation of the probability distribution of unpaid claims is of greater importance for risk management, for choosing the investment policy, and for the company's capital allocation, in addition to being fundamental to meet Solvency II and international bodies' requirements (Christiansen \& Niemeyer, 2014).

Given the uncertainty closely associated with the estimation of claims provisions, this paper came with the following question:

Is it possible to infer about the sufficiency of provisions in the balance sheet of Brazilian insurers, through the financial statements of those entities?

In view of the above prologue, this paper evaluated such possibility given the present standard of disclosure of Brazilian insurers and solely focusing on claims provisions. These are defined as the amounts of obligations estimated for the settlement of all claims that occurred up to a certain accounting closing date and that have not yet been paid, regardless of whether they were communicated to the insurers or not (Mano \& Ferreira, 2009). If it is possible to obtain the distribution of probabilities associated with the amounts of claims provisions, it will be possible that the reader of the financial statements, under a set of previously adopted assumptions, will be able to estimate the impacts of the variability of technical claims reserves, allowing their analysis spectrum to be expanded.

It was found that the task proposed by this work is possible, but given the differences in the information disclosure format, it is essential that the user of accounting information be careful when analyzing each insurance company individually.

This article, therefore, has made a practical effort to estimate the probability distribution of claims provisions for a group of insurers that have disclosed their claims development information in explanatory notes. For this purpose, the stochastic model of England and Verrall (1999) was applied to calculate the probability distribution associated with the amount of 
claims provisions of a group of insurers, considering the peculiarities in the disclosure format of each one.

Subsequently, their estimates of provisions for claims disclosed in the financial statements were analyzed, with a view to verifying the probability of their sufficiency. In this sense, it can be said that the article is a study that aims, through an empirical exercise, to infer about the uncertainty associated with the amounts of claims provisions, proposing a method of prospective analysis.

The work was structured as follows: Initially, the regulatory framework that substantiates the issue in question is presented. Subsequently, a literature review is carried out, dividing it into claims provision models and disclosure theory. After this step, the adopted methodology and the results obtained are presented. Finally, the final considerations are made, highlighting the limitations of the work.

\section{REGULATORY FRAMEWORK}

Susep is responsible for publishing the rule that deals with the dimensioning of provisions, Circular 517/2015. The Conselho Nacional de Seguros Privados' (CNSP) Resolution 321/2015 also contains several guidelines that those supervised by Susep must follow with regard to the technical provisions (Conselho Nacional de Seguros Privados, 2015). According to the Circular 517/2015 in question, every insurance company must calculate the Provision for Reported but Not Settled Claims (RBNS) and the Provision for Incurred but Not Reported Claims (IBNR) (Superintendência de Seguros Privados [Susep], 2015). While the first must be constituted with the objective of covering the expected amounts to be settled of claims that have occurred and have already been notified to the insurer until the accounting date, the second must contain the amounts expected to be settled of claims that have occurred and have not yet been notified to the insurer until the accounting date. In this context, the calculation of claims incurred but not yet paid (IBNP) is given by the sum of RBNS and IBNR.

It is worth complementing that all estimated provisions are gross of amounts to be recovered in reinsurance, in such a way that these amounts are recognized in assets, through the reinsurance asset accounts. Additionally, it should be added that all claims provisions presented are net of salvage and IBNER effects (provisions for events that have occurred, but not enough reported).

In addition to defining technical provisions, Circular 517/2015 also provides that insurers must use statistical and actuarial methods based on realistic considerations to assess the obligations of insurance contracts.

Several international bodies publish technical standards to guide insurers in preparing such estimates. Among these bodies, it is possible to mention the Casualty Actuarial Society (CAS), the Society of Actuaries (SOA), and the Actuarial Standards Board (ASB), the latter being responsible for the development and publication of the Actuarial Standard of Practice (ASOPs) reports (Actuarial Society Board, 2011a, 2011b; Casualty Actuarial Society, 2014).

Concurrently with the efforts undertaken in the North American scenario, in 2009 the European Directive 2009/138/EC (or Solvency Agreement II) (Council of the European Union, 2009) was published, with the aim of reducing the risks related to the insolvency of insurance companies in the European market (Carvalho \& Carvalho, 2019). In it, changes and new criteria were set out that European insurers should institute in the dimensioning of technical provisions.

Additionally, CPC 11, which deals with insurance contracts and is correlated with IFRS 4, provides that every insurer must prepare, at each balance sheet date, a liability adequacy test (LAT), to test whether its liabilities associated with the insurance contracts are properly measured. To do this, insurers are required to use current estimates of cash flows from their insurance contracts. If it is detected that the liability amount is insufficient, any deficiency must be immediately recognized in income (CPC, 2008).

In this sense, Caldas, Curvello and Rodrigues (2016) show that if the insufficiency found is related to provisions for premiums or mathematical provisions, the insurer must establish an additional provision called Provisáo Complementar de Cobertura (PCC). If the insufficiency occurs in the provisions for claims, the increase should take place in the case itself.

\section{LITERATURE REVIEW}

\section{Claims provision models}

McClenahan (2003) points out that until the 1970s, the concept of reaching reasonable estimates was little applied in the process of dimensioning claims provisions, and that the development of this concept started with Anker (1973) and Skurnick (1973). In this sense, Anker (1973) discusses the possibility of establishing an interval for estimated provisions, which 
can be performed subjectively or statistically, the latter using stochastic methods.

Hence, deterministic methods were widely applied. Among them, the chain ladder method was dominant in the actuarial literature to estimate the amount of claims incurred but not yet paid, the IBNP. Thus, there is considerable documentation available on the statistical basis of the chain ladder method, among which Taylor and Ashe (1983), Mack (1993) and England and Verrall (1999, 2002) stand out, of great value for theoretical understanding for the statistical basis of the model.

Simultaneously to the efforts of Skurnick (1973), Bornhuetter and Ferguson (1972) presented a seminal paper on the subject, developing the deterministic model of Bornhuetter-Ferguson, also widely applied in practice. This model uses a presumed loss ratio, obtained from historical experience.

Undoubtedly, previous works were essential for the development of an extensive line of research on the estimation of claims provisions. Initially addressing deterministic methods, such as the chain ladder, the literature was expanding to stochastic methods, given the consequent computational advance, which allowed different and more complex simulations to be adopted.

Thus, several stochastic models have been built over the last few years to produce estimates of the probability distributions associated with the amount of IBNP, given that it is possible to obtain a range of information that the deterministic model is not able to provide (England \& Verrall, 1999).

Despite its simplicity, the chain ladder method uses assumptions that can easily fail depending on the data used in the study. The chain ladder method is not indicated when the data used are volatile or when they are sensitive to external variations, such as the influence of inflation (Lemaire, 1985). Furthermore, the method only provides a point estimate of the technical provision (Chase, 2015). These limitations, when analyzed together, encouraged the actuarial academy to develop stochastic methods.

In this context, stochastic methods can be divided into two large groups: parametric and non-parametric. In parametric methods, sets of estimators are presented whose main premise is that the initial data follow a determined statistical distribution. Parametric methods are not the focus of this work and, therefore, will not be covered in the text. The non-parametric methods, on the other hand, assume that the data does not have a specific probability distribution a priori (Berrar, 2019).
Among the non-parametric stochastic methods, the bootstrap is a resampling technique that generates a distribution of empirical probability that can be used to test the accuracy of estimates and statistical inferences about a set of data (Berrar, 2019). Using Pearson residuals, this methodology was proposed by England and Verrall (1999). In this work, the non-parametric bootstrap method will be used to produce estimates of the variability of claims provisions and establish a confidence interval for the IBNP provision based on data publicly disclosed by a group of insurers. In this context, the methodology in question will be analytically presented in the next section of this work.

More recently, a range of more complex methodologies has been introduced by the scientific community. Sriram and Shi (2020) presented a new perspective for estimating claims provisions using a Dirichlet stochastic model. To do so, the authors used claims data from American insurers, comparing frequentist and Bayesian inference.

Concerned with the correlation structure in the data, Badounas and Pitselis (2020) presented an estimation model for claims provision in a longitudinal quantile model.

In turn, some studies have been adopting the neural networks to estimate the amounts of claims provisions. In this context, Gabrielli (2019) used the neural network technique to improve the Poisson overdispersion provision estimation model. Along the same lines, Ramos-Pérez, Alonso-González and NuñezVelazquez (2020) also presented a stochastic model for estimating claims provisions using neural networks. Both Lindholm, Verrall, Wahl and Zakrisson (2020) and Balona and Richman (2020) propose the use of machine learning for the estimates of claims provisions, and the second work focused on the IBNR. Nevertheless, Lopez and Milhaud (2020) propose a method using a CART (classification and regression tree) algorithm considering the delays and the development of long claims. As can be seen, more recently, there is a predominance of proposals that make use of advanced computational methods.

In the Brazilian literature, there is still a shortage of works that address the issue. Among the works developed, the work of Carvalho and Carvalho (2019) stands out, for using both a parametric and a non-parametric approach (the latter by bootstrap) to estimate the IBNR associated with the motor insurance and motor third-party liability branches of a Brazilian insurance company.

Vieira (2016), on the other hand, addressed the deterministic methodologies for claims provisions, analyzing which methodologies are applied in practice in 
the Brazilian and international scenario. In turn, Yuassa (2018) also applied the stochastic bootstrap methodology to estimate the variability of claims provisions.

Finally, Costa and Yui (2018) applied an analytical hierarchical process to compare different methods of estimating the IBNR provision of a health plan operator.

\section{Disclosure theory}

Undoubtedly, the work of Verrechia (2001) is one of the pillars of the disclosure theory. According to that author, there are three categories of research related to the subject in question. The first category, called associationbased disclosure, encompasses works that study the effect of disclosure in asset equilibrium prices and trading volume. In turn, the second category, discretionarybased disclosure, addresses studies that investigate how managers or companies themselves exercise their discretion in defining what and how to disclose, which would also involve the concept of voluntary disclosure. Finally, the third category, efficiency-based disclosure, includes the works that assess what kind of disclosure would be preferable considering a scenario of lack of knowledge and a priori information.

In this context, this work considers aspects pertaining to the second category raised by the work of Verrechia (2001), as it addresses how the disclosure of claims development criteria can impact the measurement of uncertainty associated with claims provisions, which could give rise to the possibility of earnings management practices by the managers.

Considering this discussion, recent works have related the discretionary power of managers in recognizing claims provision and its relationship with the results disclosed. In more detail, Berry-Stölze, Eastman and $\mathrm{Xu}$ (2018) investigated the relationship between overconfidence and practices of measurement of claims provisions in the property insurance industry and civil liability in the US. In turn, Hsu, Huang and Lai (2019) examined the relationship between the management of provisions and features of insurance auditors committee operating within property and liability insurance. The authors concluded that both the audit committee and the characteristics of the boards influence the disclosed values. Additionally, citing various previous works, the authors noted that the most common way to manage result in the security industry is precisely through the estimation of claims provisions.
Speaking more specifically of international literature of disclosure applied to insurance companies, it turns out that most studies are related to the level of corporate social responsibility. In this sense, the works by Ullah, Muttakin and Khan (2019), Das (2013), Sürdü, Çalışkan and Emel (2020) and Lock and Seele (2015) can be cited as examples.

Regarding the level of disclosure and its impact on the estimation of risks of ruin of insurance companies, the work of Hemrit and Arab (2011) studied the operational risk transparency component of Tunisian insurance companies, relating it to Solvency II concepts. Accordingly, Höring and Gründl (2011) also analyzed information disclosure practices in the European insurance industry, relating the level of transparency to the different characteristics of firms, such as size, risk, profitability, ownership dispersion, country of operation, and type of insurance sold, among other factors. A similar effort was undertaken by Malafronte, Starita and Porzio (2016), also in a European setting. In Brazil, the work of Veras (2016) studied the level of disclosure of insurance contracts and actuarial liabilities for Brazilian insurers for the base date of December 31, 2015.

As can be seen, there is a vast literature that seeks to assess the performance of insurance companies and its relationship with their financial strength, without necessarily having a theoretical discussion related to how the level of disclosure of insurance companies impact this estimate. Among them, it is worth mentioning the recent works by Wang (2020) and Al-Yatama, Ali, Awadhi and Shamali (2020).

Therefore, there is a gap in the disclosure literature associated with insurance entities that this work intends to fill, as most studies do not relate the level of information disclosure to the accounting information user's ability to measure the risk of uncertainty associated with claims provisions.

Among the works that strove to do something similar, Mendes, Cardoso, Mário, Martinez and Ferreira (2014) studied how the presence of inconsistent data can impact traditional insolvency models. In turn, Jackson and Wood (2013) also studied the performance of the ability to predict insolvency related to credit risk models in the UK. 


\section{RESEARCH METHODOLOGY}

Article 156 of Susep Circular No. 517/2015 establishes, through its item XIII, that:

"All information provided by each accounting standard approved by the CPC, endorsed by Susep, and the following information, referring to the individual statements, must be disclosed in the explanatory notes:

...

XIII - claims development table" (Susep, 2015, our translation)

As it turns out, insurers are required to disclose claims developments. In this sense, Caldas et al. (2016) explain that such information should go back to the period of the oldest claim for which there is still uncertainty about the amount and timing of the indemnity payment.

Despite the obligation of disclosure, it is empirically noted that there is no uniform model for the disclosure of information, so that there is a myriad of patterns identified, varying the degree of transparency in which the information is disclosed, thus making its comparability difficult, which requires that the effort to be made to answer the research question of this work is not feasible for some companies.

The granularity at which information is presented varies according to Table 1 .

Table 1. Granularity in information disclosure.

\begin{tabular}{|c|c|}
\hline Criteria & Considerations \\
\hline $\begin{array}{l}\text { As for the level of information } \\
\text { aggregation }\end{array}$ & If applicable, it is usual for the data to be disclosed for both consolidated data and parent company data. \\
\hline As for the type of claim & Whether the claims are judicialized or administrative. \\
\hline As for reinsurance & Some insurers choose to disclose claims development information both gross and net of reinsurance. \\
\hline $\begin{array}{l}\text { As for salvage and } \\
\text { subrogations }\end{array}$ & Insurers may present the gross or net results of salvage and subrogation. \\
\hline $\begin{array}{l}\text { Regarding the variability of } \\
\text { period criteria }\end{array}$ & Claims can be filed by year of occurrence, year of registration, year of notice, or year of subscription. \\
\hline $\begin{array}{l}\text { Regarding the number of } \\
\text { development periods }\end{array}$ & $\begin{array}{l}\text { Claims are often presented in triangles whose development can vary from one to } 10 \text { periods. Some insurers may choose } \\
\text { to present more than } 10 \text { periods, which is not the most usual pattern. }\end{array}$ \\
\hline As for the type of data & Claims development can be presented in different ways, namely: claims incurred or claims paid. \\
\hline
\end{tabular}

Note. Prepared by the authors.

At this point, it is convenient to detail more incisively the last point addressed in Table 1. As Caldas et al. (2016) explain, by presenting the development table of claims incurred in a year and the balances of that same set of claims in subsequent years, the user of financial information can calculate the error of the insurer's estimate in the range of periods covered. This procedure makes it possible to assess the accuracy of the estimate of claims upon initial recognition, with a view to assisting the process of future cash flow analysis.

It is essential to note that even the chain ladder method can be made based on different data sources, having different estimates calculated according to the type of data. That is, it is possible to obtain an estimate of the IBNP based on the development of both claims incurred ${ }^{1}$ and claims paid.
Considering that the present study focuses on the application of a stochastic method to calculate the IBNP, the chain ladder method for the development of paid claims ${ }^{2}$ will be presented, because its understanding will be essential for the application of the stochastic model.

Briefly, the chain ladder method uses incremental and cumulative data from claims already paid and recorded to produce a final cumulative single estimate. This estimate represents the total development of all claims paid in a certain time interval until the end of the chosen development period, called ultimate (England \& Verrall, 2002).

For the model, it is assumed that the data will be arranged in triangles called runoff (England \& Verrall, 2002). Consider a group of claims and that each claim that makes up this group is settled in the year of its occurrence or in $n$ subsequent years (Schmidt, 2006). These claims can be incrementally modeled as follows: 
$\left\{D_{i j}: i=1, \ldots, n ; j=1, \ldots, n-i+1\right\}$

where:

$D$ can represent the amount of claims paid or the claim count;

$i$ refers to the lines of the triangle and can represent the year of subscription or year of occurrence, as in the present study;

$j$ refers to the columns of the triangle and can represent the number of years between the occurrence and the settlement of the claim, called the development period.

The chain ladder method has the objective of filling the values below the main diagonal of this matrix and, with this, obtain the ultimate of each $n$ year of occurrence, through the sum of each row of the filled matrix of the incremental triangle.

The group of claims can also be modeled cumulatively using the formula:

$C_{i j}=\sum_{k=1}^{j} D_{i k}$

where:

$C$ represents the sum of the values of $D$ from each year of occurrence $i$ through year of development $j$.

After modeling the cumulative amount of claims for each year of occurrence and known year of development, the estimates of the development factors (DF) are defined, following the equation:

$f_{j}=\frac{\sum_{k=1}^{n-j} C_{k, j+1}}{\sum_{k=1}^{n-j} c_{k j}} ; 1 \leq j \leq n-1$

where $f_{j}$ represents the estimate of the development factor of the $j$-th year of development.

Then, the development factors are accumulated by the following product:

$\hat{f}_{j}=\prod_{k=1}^{j} f_{j}$

The ultimate of each occurrence period is then calculated by applying for each occurrence period, as follows:

$\hat{C}_{i, n}=C_{i, n+1-i} \times \hat{f}_{j} ; 0 \leq i \leq n$

where $\hat{C}_{i, n}$ represents the ultimate of each year of occurrence.
The development of more recent claims is expected to occur in a similar way to the development of claims observed in the past.

The result of the chain ladder method is a simple estimate of the ultimate values for each $n$ year of occurrence. To obtain the IBNP provision, we must subtract from the ultimate of each year of occurrence the value of the main diagonal of the accumulated triangle of claims payments, as exemplified below:

$I B N P=\sum_{i=1}^{n} \hat{C}_{i, n}-C_{i, n+1-i}$

Considering that this model is deterministic and, consequently, only provides a point estimate of the IBNP, the non-parametric bootstrap stochastic method will be presented, as suggested by England and Verrall (1999).

Consider a data set with an empirical distribution of size $n$ and that each observed data receives a probability $1 / n$. The bootstrap sample can be defined as being random, of size $n$ and taken from the initial sample with replacement. In this way, any data from the initial sample may appear several times or not at all in the bootstrap sample.

First, the triangle of claims paid on an accumulated basis must be modeled and the development factors for each period of development must be obtained using Equation (7):

$f_{j}=\frac{\sum_{k=1}^{n-j} C_{k, j+1}}{\sum_{k=1}^{n-j} C_{k j}} ; 1 \leq j \leq n-1$

Next, a triangle is created keeping only the main diagonal with the accumulated values of claims paid and estimating the values above the main diagonal. These values will be recurrently estimated by dividing the value of the development period $n$ by the development factor of $n-1$.

You must then model the incremental triangles from the original cumulative triangle and the estimated cumulative triangle and, by applying Equation (8) at each position of the triangle, calculate the Pearson's dimensionless residual triangle $\hat{r}_{i, j}$ :

$\hat{r}_{i, j}=\frac{D_{i, j}-m_{i, j}}{\sqrt{m_{i, j}}}$

where:

$D_{i, j}$ represents the value at position $(i, j)$ of the original incremental triangle;

$m_{i, j}$ represents the value at position $(i, j)$ of the estimated incremental triangle. 
With the triangle of residuals constructed, the variance of the residuals is calculated using Equation (9):

$\phi=\frac{\sum_{i=1}^{N} \hat{r}_{i}^{2}}{N-p}$

where:

$N$ represents the total of observations;

$p$ represents the number of parameters estimated by the model.

In this context, Albarrán and Alonso (2011) recommend that the estimated model be:

$\eta_{i, j}=C+\alpha_{i}+\beta_{j}$

where:

$\alpha_{0}=\beta_{0}=0$

$i$ is the number of years of occurrence minus 1 ; and

$j$ is the number of years of development minus 1 .

The bootstrap method is then applied through the construction of a new triangle containing a resampling of Pearson residuals performed with replacement. All residues must have the same probability of being picked in the resampling.
Next, it is necessary to regenerate the incremental amounts of claims paid from the residuals triangle resampled in the previous step, according to Equation (11):

$\widehat{D}_{i, j}=\hat{r}_{i, j} \times \sqrt{m_{i, j}}+m_{i, j}$

The incremental triangle resulting from the previous step must be accumulated and a new IBNP estimate must be calculated by the traditional chain ladder method.

The process will be complete after repeating the resampling of the Pearson residuals triangle, regenerating the claims paid amounts, and calculating new IBNP estimates several times.

For the substantiated empirical effort, the work was undertaken with the data publicly disclosed by the financial statements of five Brazilian insurance companies, for the year 2019. To define which insurance companies would be used in the study, the financial statements of 31 Brazilian insurance companies that operated until December 2019 were analyzed, so that they made up more than $90 \%$ of the written premiums in the Brazilian market in 2019 for nonlife insurance.

Table 2 presents the list of the 31 insurers evaluated, as well as their Susep code and main fields of activity.

Table 2. Insurers initially analyzed.

\begin{tabular}{|c|c|}
\hline Susep code & Main branches of activity* \\
\hline 06467 & Automotive, MTPL, Business Comprehensive and Residential Comprehensive \\
\hline 05177 & Automotive, Property, Transport, Life and Rural \\
\hline 02798 & Transport, Casualty, Financial and Equity Risks \\
\hline 02852 & Extended Guarantee, Public and Private Sector Guarantee, Property and Casualty \\
\hline 05355 & Automotive, MTPL and Assistance \\
\hline 01414 & Automotive, MTPL and Assistance \\
\hline 05444 & VGBL, Life, Automotive and PGBL \\
\hline 06785 & Life and Rural \\
\hline 05631 & Group Life, Automotive, Business Comprehensive and Housing \\
\hline 02933 & Miscellaneous Risks, Extended Warranty and Microinsurance \\
\hline 06513 & Group Life, Life, Casualty, Transrisks and Financial Risks \\
\hline 04669 & Financial, Rural, Transport, Oil and Casualty \\
\hline 06122 & Property, Casualty and Financial Risks \\
\hline 05908 & Automotive, MTPL, Personal Accidents and Lender \\
\hline 01571 & Property, Transport e Casualty \\
\hline 06572 & Automotive, Property and Transport \\
\hline 05142 & Group Life, Lender and Personal Accidents \\
\hline 05185 & Automotive, Property and Life, Transport \\
\hline
\end{tabular}


Table 2. Insurers initially analyzed (Continued).

\begin{tabular}{cl}
\hline Susep code & \\
\hline 02062 & Extended Warranty \\
06238 & Automotive, Property, Rural and Aeronautical \\
06602 & Automotive, Property and Transport \\
05886 & Automotive, MTPL, Business Comprehensive, Residential Comprehensive and Security \\
03069 & Rental Guarantee and Security \\
06751 & Transport, Automotive, Property and People \\
05720 & Automotive, Property, Transport, Group Life and Rural \\
05118 & Automotive, MTPL, Assistance, Residential Comprehensive and Condominium Comprehensive \\
06190 & Automotive, Property and Life \\
06653 & Public Sector Guarantee, Lender, Housing and Rural \\
03671 & Lender and Automotive \\
05495 & Extended Warranty, Miscellaneous Risks, Automotive, Group Life and Lender \\
06564 & Residential Comprehensive, Housing, Business Comprehensive and Miscellaneous Risks \\
\hline
\end{tabular}

Note. *VGBL and PGBL: Brazilian pension products. Prepared by the authors.

As one of the objectives of the work is to verify the sufficiency level of the provisions (together with the solvency capital level) associated with the IBNP estimate by the method of England and Verrall (1999), it is necessary that for this comparison to be valid, the data available in the runoff triangles of the explanatory notes are grouped by year of occurrence, considering that the model used is based on this premise.

The other conditions used in choosing insurers refer to the existence of at least 10 years of claims development in the triangles; the grouping of claims made available will be in the form of accumulated paid claims; and finally, that the data presented is gross of reinsurance.

Of the 31 insurers analyzed, only five presented claims development data as explained. To demonstrate the difficulty in choosing the insurers for the substantiated study, Tables 3, 4,5 , and 6 show the variability that exists in the format of the disclosure of data for the 31 analyzed insurers.

Table 3 shows that of the 31 insurers analyzed, 10 present the development of claims from the year of notification, 18 from the year of occurrence, and three from the year of registration of the claims.

In turn, 10 different development periods were identified among the 31 insurers. Table 4 presents the number of insurers for each period class.

On the other hand, Table 5 indicates that 16 companies out of the 31 analyzed present the triangle for the development of accumulated paid claims.
Table 3. Regarding the variability of period criteria.

\begin{tabular}{|c|c|}
\hline $\begin{array}{c}\text { Claims development from the } \\
\text { date of }\end{array}$ & Number of insurance companies \\
\hline Notice & 10 \\
\hline Occurrence & 18 \\
\hline Registry & 3 \\
\hline
\end{tabular}

Note. Prepared by the authors.

It was also possible to verify that 27 insurers analyzed had gross reinsurance development triangles, so that for four insurers, the explanatory note did not allow identifying whether the data were gross or net of reinsurance.

Table 4. Variability of periods of development.

\begin{tabular}{|cc}
\hline Development period $^{*}$ & Number of insurance companies \\
\hline 20152019 & 2 \\
20142019 & 7 \\
$2014+2019$ & 3 \\
20132019 & 1 \\
$2013+2019$ & 1 \\
20122019 & 2 \\
20112019 & 4 \\
20102019 & 6 \\
20092019 & 4 \\
\hline $2008+2019$ & 1 \\
\hline
\end{tabular}

Note. Prepared by the authors. ${ }^{*}$ symbol ' + ' means that claims from previous periods are accumulated in the period indicated. 
Table 5. Number of insurers that have a paid claims triangle.

\begin{tabular}{|c|c|}
\hline $\begin{array}{c}\text { Does it have a paid claims } \\
\text { triangle? }\end{array}$ & Number of insurance companies \\
\hline Yes & 16 \\
\hline No & 15 \\
\hline
\end{tabular}

Note. Prepared by the authors.

Table 6. Number of insurers that have a gross reinsurance runoff triangle.

\begin{tabular}{lc}
\hline Are claims gross of reinsurance? & Number of insurance companies \\
\hline Yes & 27 \\
No & 0 \\
Uninformed & 4 \\
\hline
\end{tabular}

Note. Prepared by the authors.
The data used in this analysis can be found in the explanatory notes that contain the development claims for each company. In view of the myriad of disclosure criteria and considering the peculiarities of the England and Verrall (1999), model, the empirical effort was undertaken with five insurance companies that disclosed the information that allowed the estimation of the IBNP as defined, that is: there are at least 10 years of claims development in the triangle, the claims are grouped in the form of paid claims, the claims development starts from the year of occurrence, and the data is gross of reinsurance. Thus, the analyses are limited exclusively to the studied insurers. Table 7 summarizes how the data were presented by these companies.

Table 7. Granularity in the disclosure of information of the analyzed insurers.

\begin{tabular}{ll}
\hline Criteria & Considerations \\
\hline $\begin{array}{l}\text { As for the level of information } \\
\text { aggregation }\end{array}$ & $\begin{array}{l}\text { There was no consolidation in the group's financial statements, so the data provided are individual. } \\
\text { Two insurance companies presented administrative and judicial claims in the same triangle, without any distinction } \\
\text { between them. The remaining three insurers presented the triangles separately. For the empirical effort undertaken in } \\
\text { these three insurers, the triangles of accumulated administrative payments were added to the judicial ones, so that the } \\
\text { criterion remained uniform among the five insurers. }\end{array}$ \\
$\begin{array}{l}\text { As for the type of claim } \\
\text { The five insurers have disclosed claims development data both gross and net of reinsurance. As the objective is to calculate } \\
\text { the probability distribution associated with the IBNP and compare it with the amount recognized in the balance sheet } \\
\text { and the latter is gross of reinsurance, the model used will be based on the gross data. }\end{array}$ \\
$\begin{array}{l}\text { As for reinsurance } \\
\text { As for salvage and subrogation }\end{array}$ \\
$\begin{array}{l}\text { four of them note that the triangles are gross. Therefore, as the technical provisions data in the balance sheet are net of } \\
\text { salvage, necessary care was taken when comparing the data in the financial statements. In the case of the company that } \\
\text { did not discriminate whether the data is gross of salvage and subrogation, it was assumed that they are net. }\end{array}$ \\
$\begin{array}{l}\text { Regarding the variability of } \\
\text { period criteria }\end{array}$ \\
$\begin{array}{l}\text { Regarding the number of } \\
\text { development periods }\end{array}$ \\
$\begin{array}{l}\text { Claims were developed from the year of occurrence. } \\
\text { As for the type of data }\end{array}$
\end{tabular}

Note. Prepared by the authors.

Calculations were performed using Microsoft Excel ${ }^{\oplus}$. In this study, 10,000 IBNP estimates were made using the bootstrap method. Data from 2010 to 2019 were considered for the achievement of the runoff triangles (a total of 10 years).

To facilitate the analysis of results, this work will adopt the following pattern:
- Insurer A: Susep Code 06467;

- Insurer B: Susep Code 05185;

. Insurer C: Susep Code 06751;

- Insurer D: Susep Code 05720;

- $\quad$ Insurer E: Susep Code 06190. 


\section{RESULTS}

Figures 1,2,3, 4, and 5 show the cumulative percentage estimates of claims paid for each period of development of each company. Such estimates were created using the chain ladder method with development factors generated by the weighted average of the previous periods. As a result, the data indicate that the claims development of the five insurers takes place in a similar way, that is, approximately $94 \%$ of the total amount of claims is paid within three years from the year of occurrence of the claims. Thus, it can also be inferred that the five insurance companies operate mainly with shorter tail insurance.

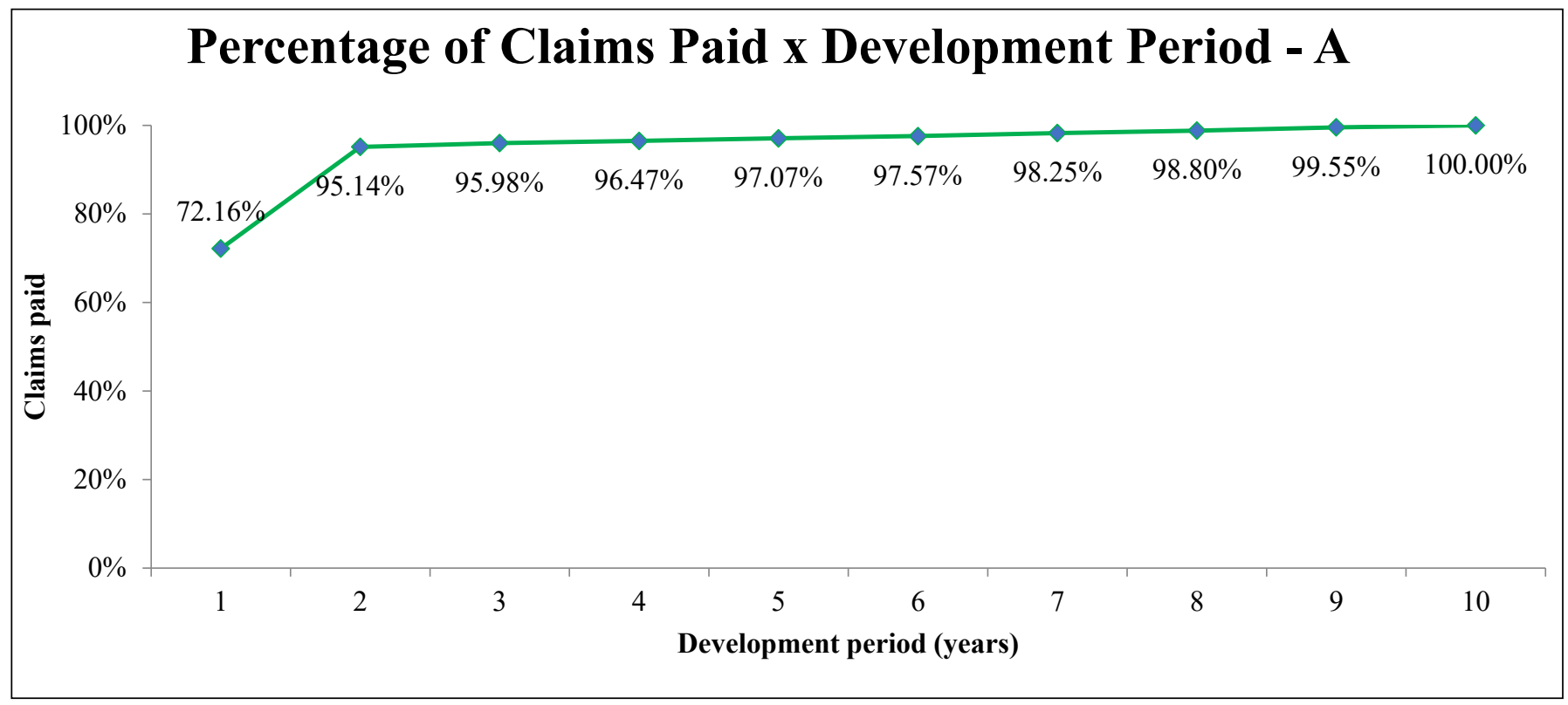

Figure 1. Development of insurer A's accumulated claims payments.

Source: Prepared by the authors.

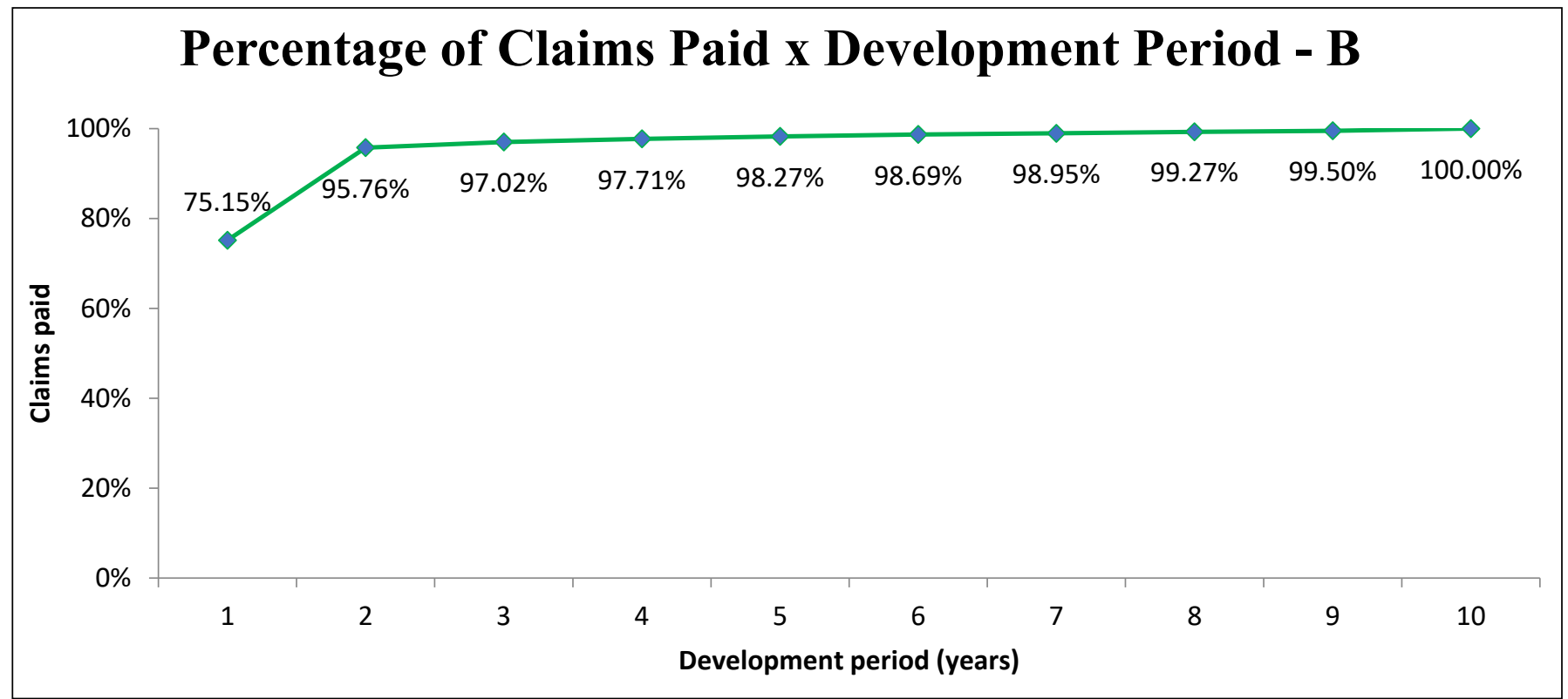

Figure 2. Development of insurer B's accumulated claims payments.

Source: Prepared by the authors. 


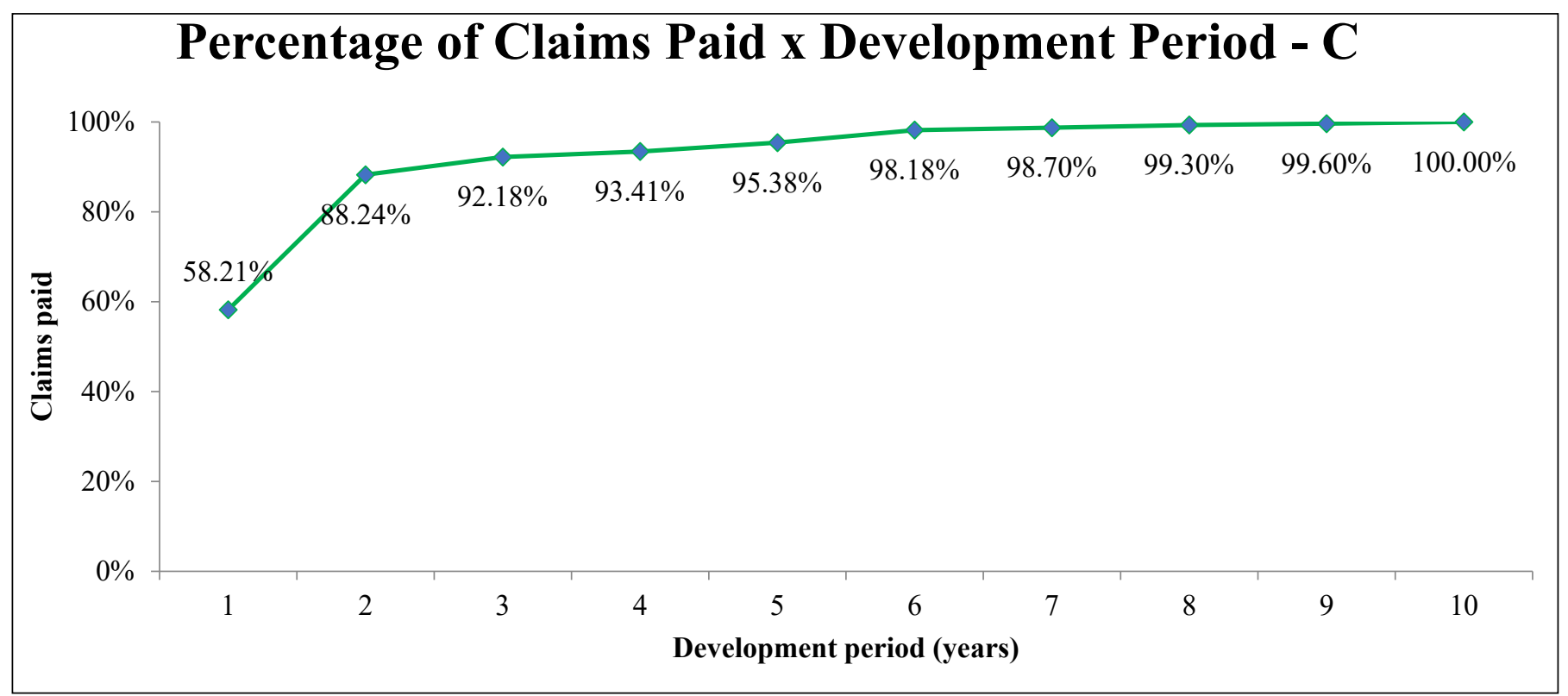

Figure 3. Development of insurer C's accumulated claims payments.

Source: Prepared by the authors.

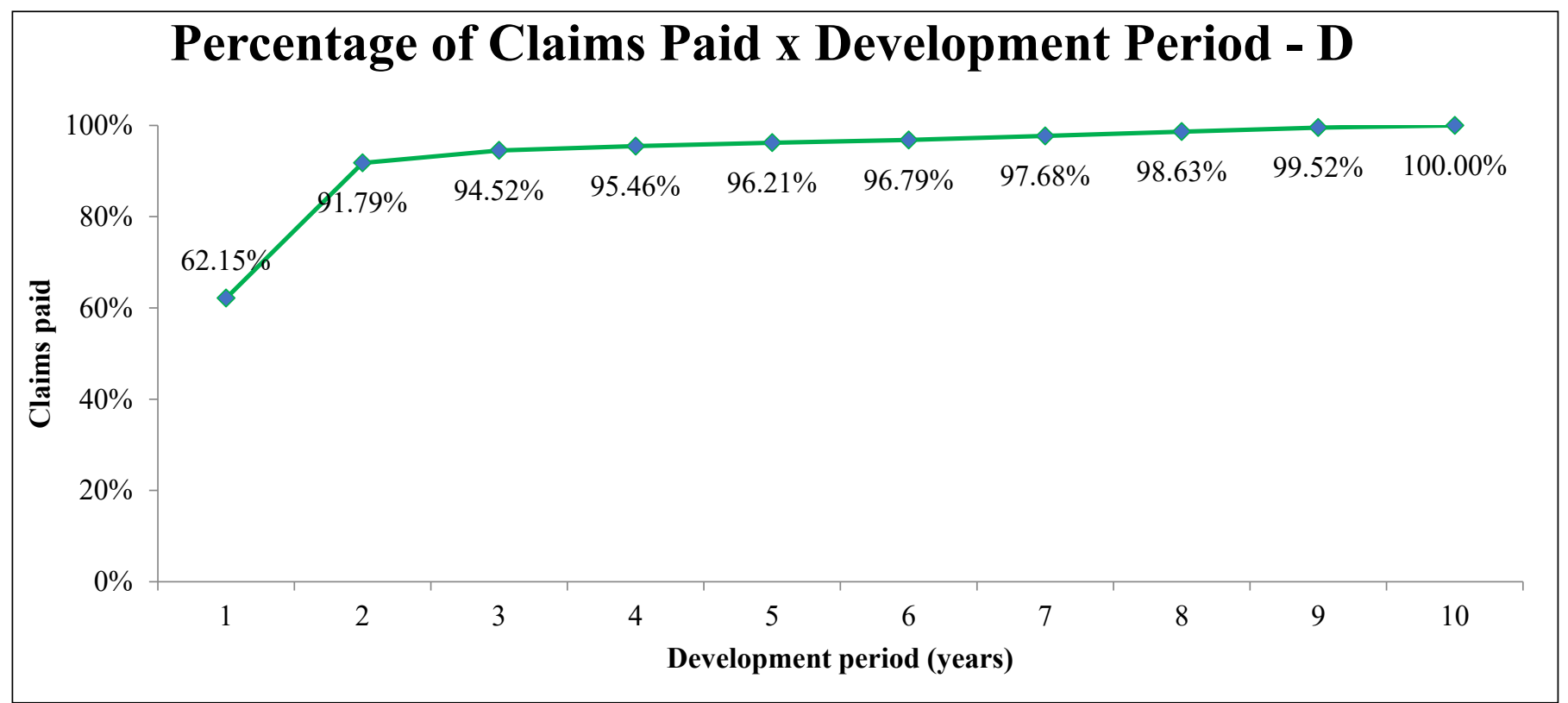

Figure 4. Development of insurer D's accumulated claims payments.

Source: Prepared by the authors. 


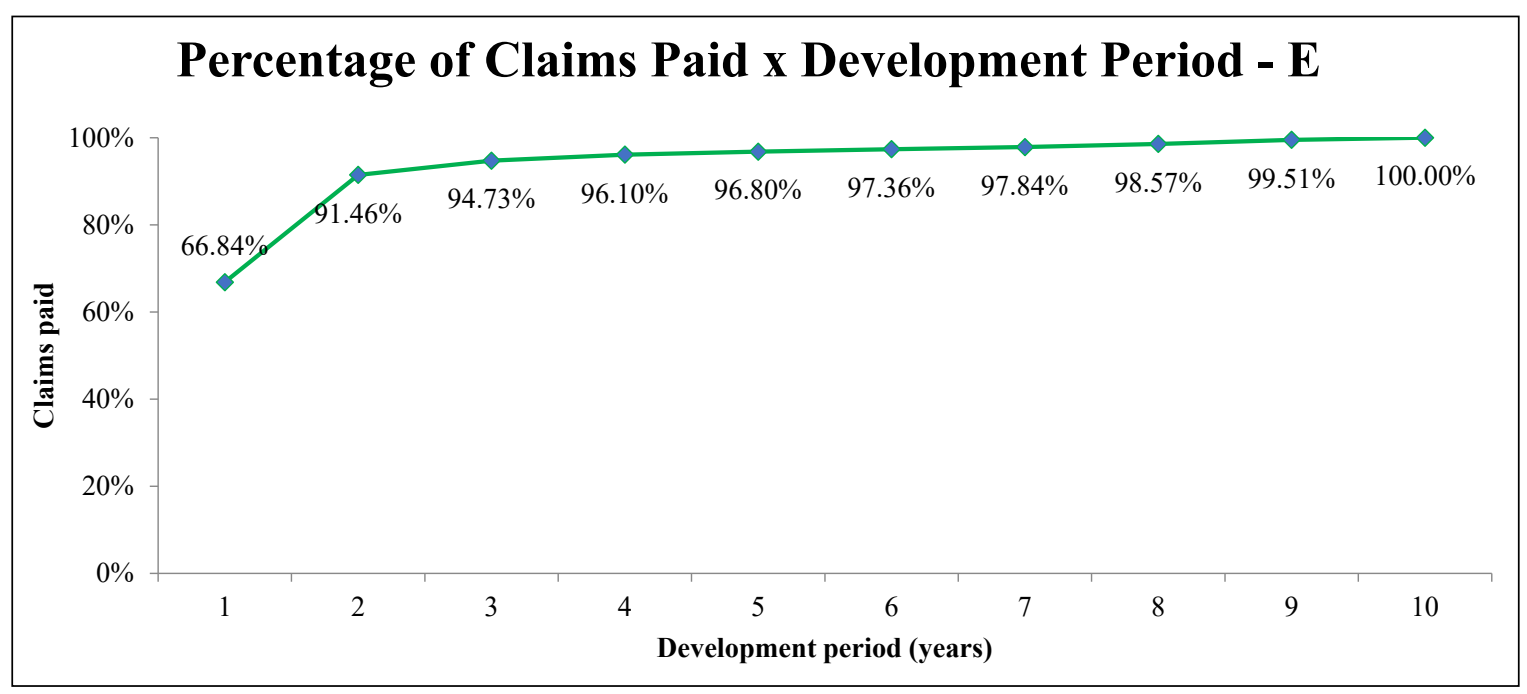

Figure 5. Development of insurer E's accumulated claims payments.

Source: Prepared by the authors.

Although cumulative claims paid triangles indicate that companies' insurance is short tailed, even after 10 years of occurrence, it is not possible to be sure that all claims have been settled, as claims that have gone to court can even take decades until the res judicata, for example. This is one reason why it is important to identify the probability distribution of an insurer's IBNP at each accounting date. The distribution of probabilities helps the actuary in determining capital based on underwriting risk and in choosing who, insured or shareholder, will be more burdened so that the risk of ruin remains low.

Table 8 presents the descriptive statistics obtained from simulations of the amount of IBNP for each company studied. It can be observed positive kurtosis values for the five companies, indicating that the distributions are slightly leptokurtic. However, as seen in Figures 1, 2, 3, 4, and 5, the IBNP distribution of any studied company cannot be said to have heavy tails, as the kurtosis coefficient values are close to zero. Additionally, it can also be inferred that all distributions also have a slight asymmetry to the right. Furthermore, the coefficients of variation of the probability distributions of the five insurers were within the range between $11 \%$ and $20 \%$, which denotes a not so high variability.

It is imperative to point out that insurers have different sizes. This can be verified by analyzing the average IBNP calculated. By way of illustration, while the insurance company A had an average IBNP of R $\$ 119.02$ million, the insurance company $E$ presented an average of $R \$ 1,544.58$ million, showing the size differences.

Table 8. Descriptive statistics of the point estimates of IBNP estimated by resampling of bootstrap.

\begin{tabular}{|c|c|c|c|c|c|}
\hline Descriptive Statistics & Insurer A & Insurer B & Insurer $\mathrm{C}$ & Insurer D & Insurer $\mathrm{E}$ \\
\hline Average ( $\mathrm{R} \$$ million $)$ & 119.02 & 779.99 & 262.48 & $1,136.14$ & $1,544.58$ \\
\hline Percentile $50 \%$ ( $\mathrm{R} \$$ million) & 118.75 & 775.11 & 259.58 & $1,124.44$ & $1,539.17$ \\
\hline Percentile 75\% ( $\mathrm{R} \$$ million $)$ & 124.66 & 811.77 & 279.33 & $1,234.24$ & $1,635.88$ \\
\hline Percentile 95\% (R\$ million) & 134.52 & 882.46 & 314.05 & $1,424.42$ & $1,785.36$ \\
\hline Percentile 99\% (R \$ million) & 142.26 & 972 & 342.27 & $1,614.61$ & $1,909.92$ \\
\hline Standard deviation ( $\mathrm{R} \$$ million) & 8.76 & 57.1 & 27.35 & 158.18 & 139.92 \\
\hline Coefficient of variation & 0.11 & 0.11 & 0.16 & 0.2 & 0.13 \\
\hline Kurtosis & 0.26 & 2.12 & 0.85 & 1.64 & 0.2 \\
\hline Asymmetry & 0.24 & 0.87 & 0.67 & 0.56 & 0.24 \\
\hline Range (R\$ million) & 70.41 & 471.25 & 217.03 & $1,584.88$ & $1,245.6$ \\
\hline Minimum ( $\mathrm{R} \$$ million $)$ & 88.75 & 595 & 183.83 & 552.74 & 988.17 \\
\hline Maximum ( $\mathrm{R} \$$ million) & 159.16 & $1,066.25$ & 400.87 & $2,137.62$ & $2,233.77$ \\
\hline
\end{tabular}

Note. Prepared by the authors. 
Thus, histograms were generated with empirical probability distributions of the IBNP performed with the data obtained by the bootstrap technique proposed by England and Verrall (1999) for each of the insurers. These results are shown in Figures 6, 7, 8, 9, and 10.

For each of the respective figures, the histogram can be interpreted as follows: in blue, there is the percentile of the amount of provisions for claims gross of salvage and reinsurance recognized in the financial statements. For example, according to the estimates obtained through the application of the bootstrap technique, insurer $\mathrm{C}$ presented a percentile of $96.3 \%$ for its claim provision amount, that is, it is estimated that there is a probability of only $3.7 \%$ that the amount recognized with the provisions for claims will be exceeded.

A very important discussion that is linked to IBNP distributions is the need for capital that insurers must maintain in equity to be able to face the risk that the provisions for claims originally recognized in the financial statements are exceeded. Thus, Susep, following the dictates of Solvency II, requires that all insurance companies maintain an additional level of capital. This estimate of capital needs is one of the risk-based capital components, called underwriting risk-based capital (risk that premiums are insufficient to pay the indemnities). According to Altieri, Fraga and Veiga (2014), capital requirements can be defined as a reserve that will face a risk measure of the empirical probability distribution of IBNP. In this context, every insurer in Brazil shall maintain a level of adjusted surplus (PLA in Brazilian Portuguese), ${ }^{3}$ in a way that this must be greater than the higher value between base capital and risk based capital ${ }^{4}$. Therefore, to try to estimate the true risk of insufficiency of claims provisions to which an insurer is subject, in yellow it is showed the percentile that represents the sum of the amount of claims provisions gross of salvage and reinsurance with which the insurer maintains in PLA. Thus, although the insurer $\mathrm{C}$ has an estimated probability of $3.7 \%$ that the actual amount of IBNP exceeds the provisions recognized in its financial statements, when considering the amount kept in PLA, it possessed capital adequacy, so that probability of the true value of the IBNP exceeding that recognized in technical provisions (and consequently linked to some assets, for legal purposes) and what it maintains in PLA converges to zero.

It is worth making some reservations about the reasoning used in this work. The first is that the PLA, originally, should be sufficient to prevent not only underwriting risk from materializing, but also credit, market, and operational risk. Thus, the adopted estimate has the limitation of not considering the other risks, given that the empirical effort is limited to analyzing the risk of insufficiency of the estimated provisions for claims. However, this problem is resolved as underwriting risk is the most significant portion of risk to which an insurer is subject. Analyzing the minimum risk capital explanatory notes, it was found that for the sample of insurers in question, the underwriting risk corresponds to approximately $80 \%$ of the solvency risk to which the insurers are subject, such that the amount of the PLA, for the most part, is intended precisely to cover these risks.

Another important point concerns the study of the differences found and their implications. As shown in Figures 6, 7, 8, and 10, insurers A, B, C, and E, when considering the PLA, have a low risk of insufficiency of claims provisions, that is, the probability of the sum of the amount maintained in claims reserves and in PLA being exceeded converges to zero. However, the percentile referring to the amount of technical claims reserves varies substantially, indicating that there are strong indications that there are different management decisions regarding the choice of who, insured or shareholder, will be more burdened, so that the risk of insufficient provision for claims remains low.

Lower claim provision levels necessarily lead to lower premiums charged to customers and higher profits recognized in the period. In this context, insurer E, for example, is recognizing a higher level of provisions (in relative terms), so there are signs that they do not need to burden their shareholders as much through a higher level of PLA. Nevertheless, when recognizing an amount of claims provisions that already has a probability of being exceeded converging to zero, it can be said that there are indications that the provisions are oversized, which compromises the profitability of the period and the distribution of dividends, being, therefore, an example of extremely conservative estimates. For its part, the insurer A presented a probability of $98.7 \%$ that the amount of recognized obligations in claims provisions will be overcome, so that, in order to keep the probability of exceeding the claims provision also low (converging to zero), the insurer chose to maintain a high level of PLA (in relative terms). From the customer's point of view, this procedure lowers insurance and brings competitiveness. In turn, from the shareholders' point of view, this apparent underestimation of the level of the claims provisions leads to two contradictory phenomena: if, on the one hand, recognized provision expenses become lower and profit grows, increasing the distribution of dividends, on the other hand, the members must maintain a large amount of PLA in the form of reserves to maintain the probability of exceeding the claims provisions also low, thus burdening them. It is inferred, therefore, that the level of recognized claims provisions can be used for the purpose of earnings management, as recent literature has 
already been exploring (Berry-Stölze, Eastman \& Xu, 2018; Hsu, Huang, \& Lai, 2019).

With respect specifically to Figure 9, according to the model developed, insurer $\mathrm{D}$ has a probability of $11.2 \%$ of having the sum of its amount in claims reserves with PLA being exceeded. However, two important considerations must be made. Initially, it should be remembered that all claims reserves are gross of reinsurance, so that a part of the reinsurance assets refers to the indemnities that the insurer will receive for claims that have already occurred. Therefore, in practice, every insurance company still has an amount of indemnities to be recovered from reinsurers. In addition to the above point, it was found that the specific situation of insurer D was due to an unusual year in its sample, so that the effects were mitigated when considering the effect of reinsurance. However, it is essential to make it clear that this was due to claims of outliers that were covered by a reinsurance instrument, and therefore were not a problem. It is worth complementing that the bootstrap model adopted in this article, as noted above, is sensitive to the presence of extreme values, in such a way that estimates can be biased (Lemaire, 1985). It appears, therefore, that the findings of this work cannot and should not be considered individually, but together with a broader perspective that considers other methodologies and business changes, such as the introduction of new products, the sale of portfolios, and the eventual termination of partnership contracts.

Thus, if the amount that the insurer maintains in claims provisions (which necessarily correspond to some guaranteeing assets) is considered with the PLA and the amount to be recovered in claims from reinsurers, insurer $\mathrm{D}$ has a probability of insufficiency of provisions close to zero.

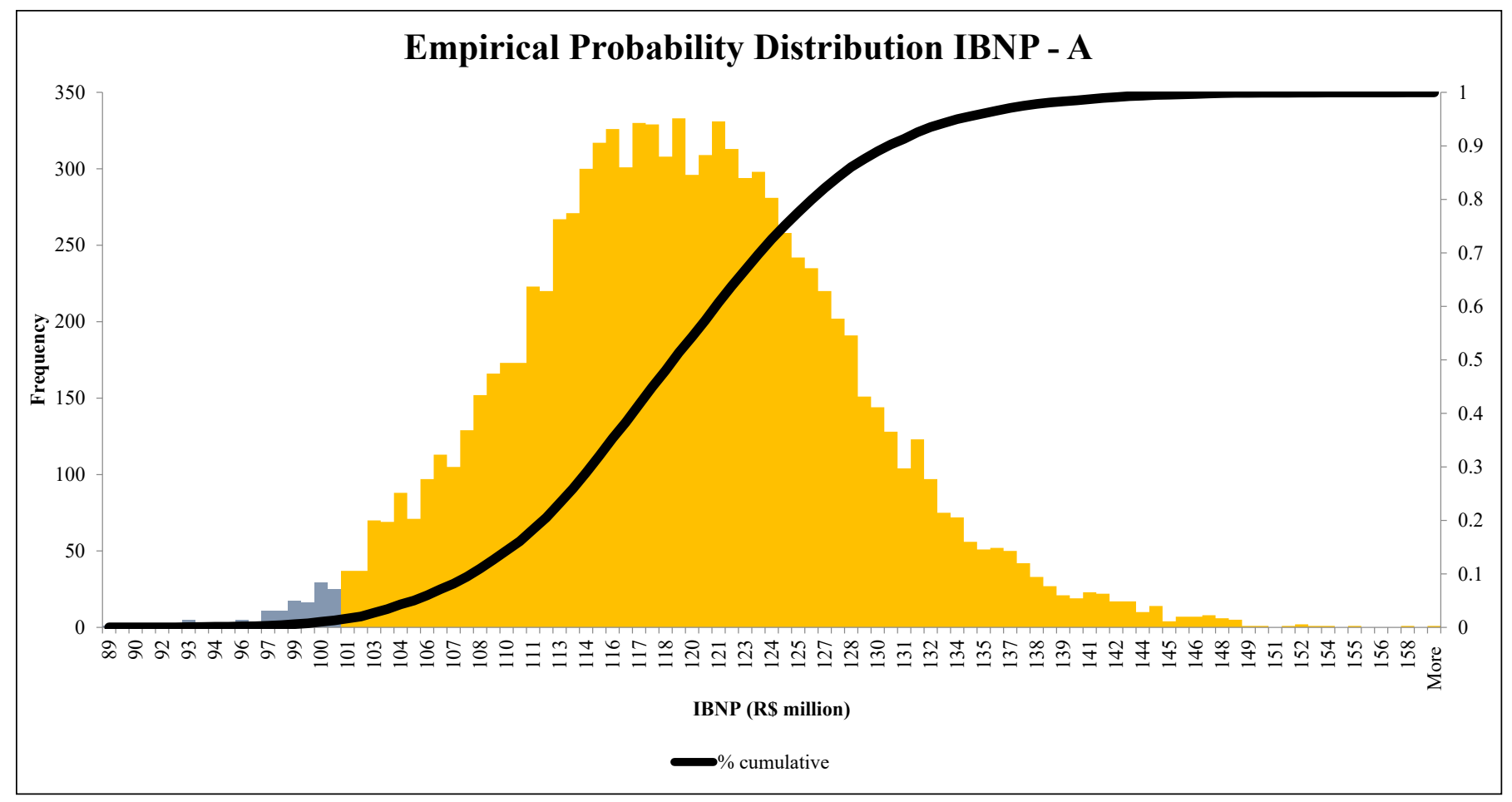

Figure 6. Empirical probability distribution of IBNP estimated by bootstrap — Insurer A.

Source: Prepared by the authors. 


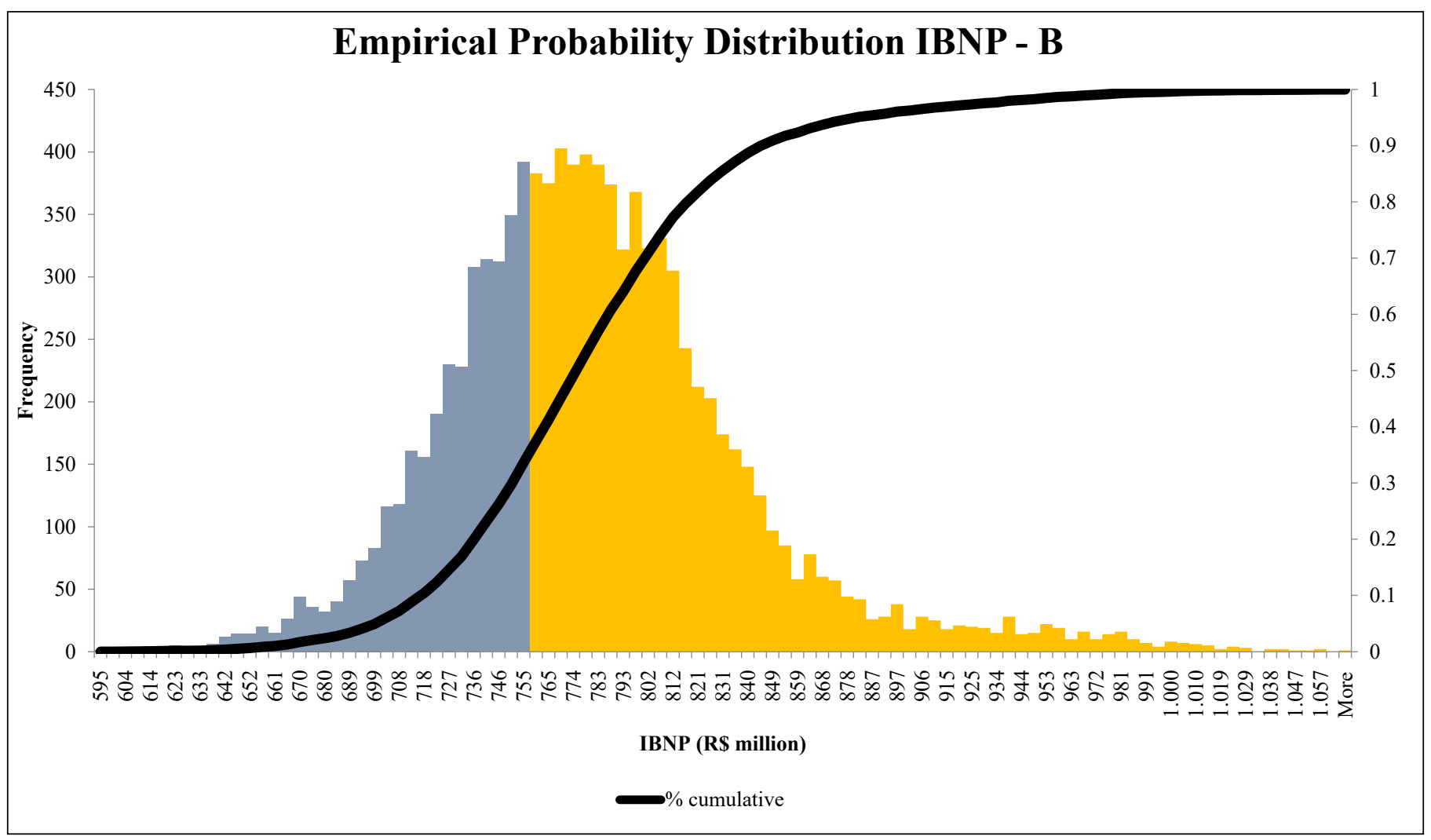

Figure 7. Empirical probability distribution of IBNP estimated by bootstrap — Insurer B.

Source: Prepared by the authors.

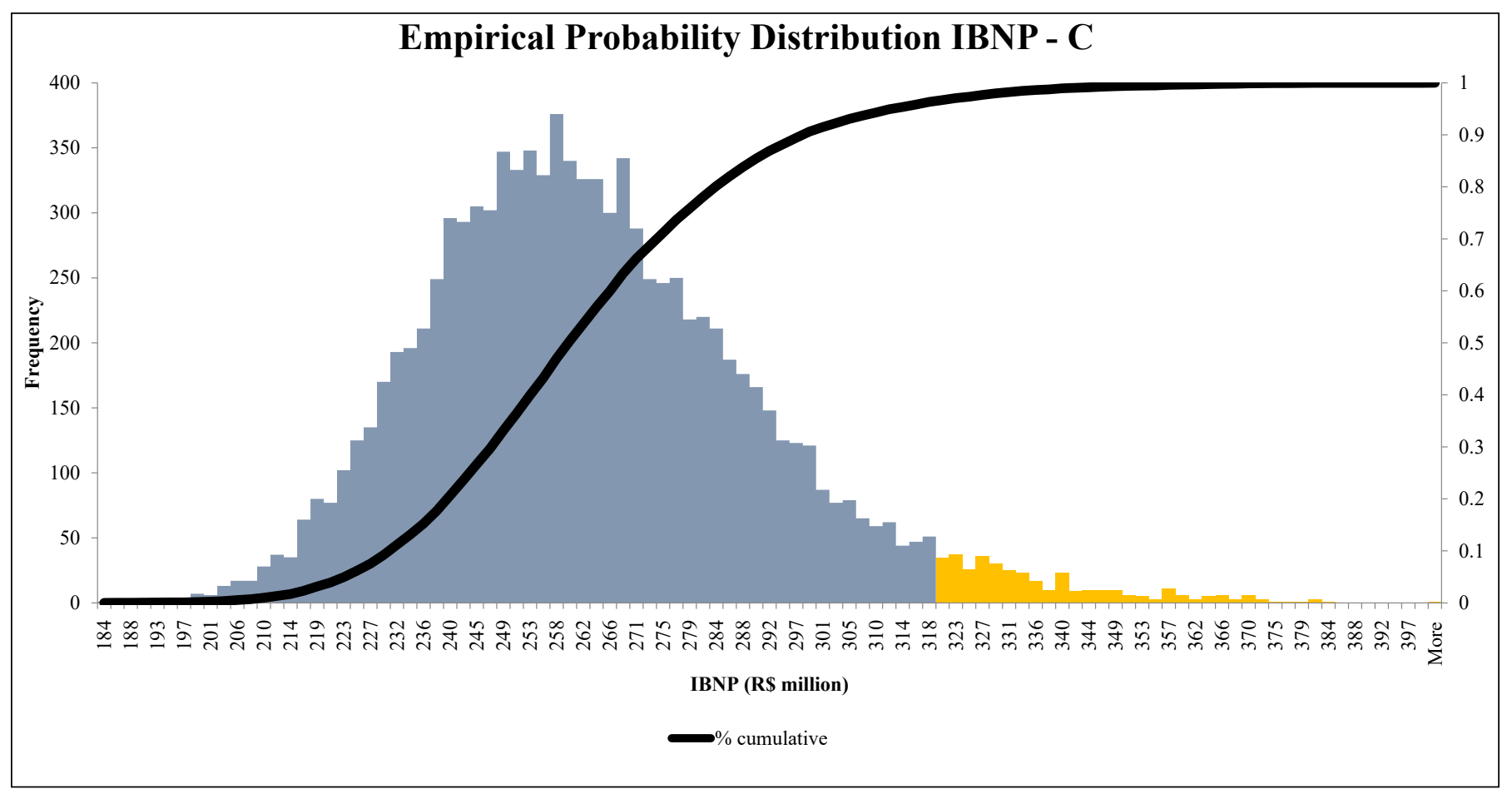

Figure 8. Empirical probability distribution of IBNP estimated by bootstrap — Insurer C.

Source: Prepared by the authors. 


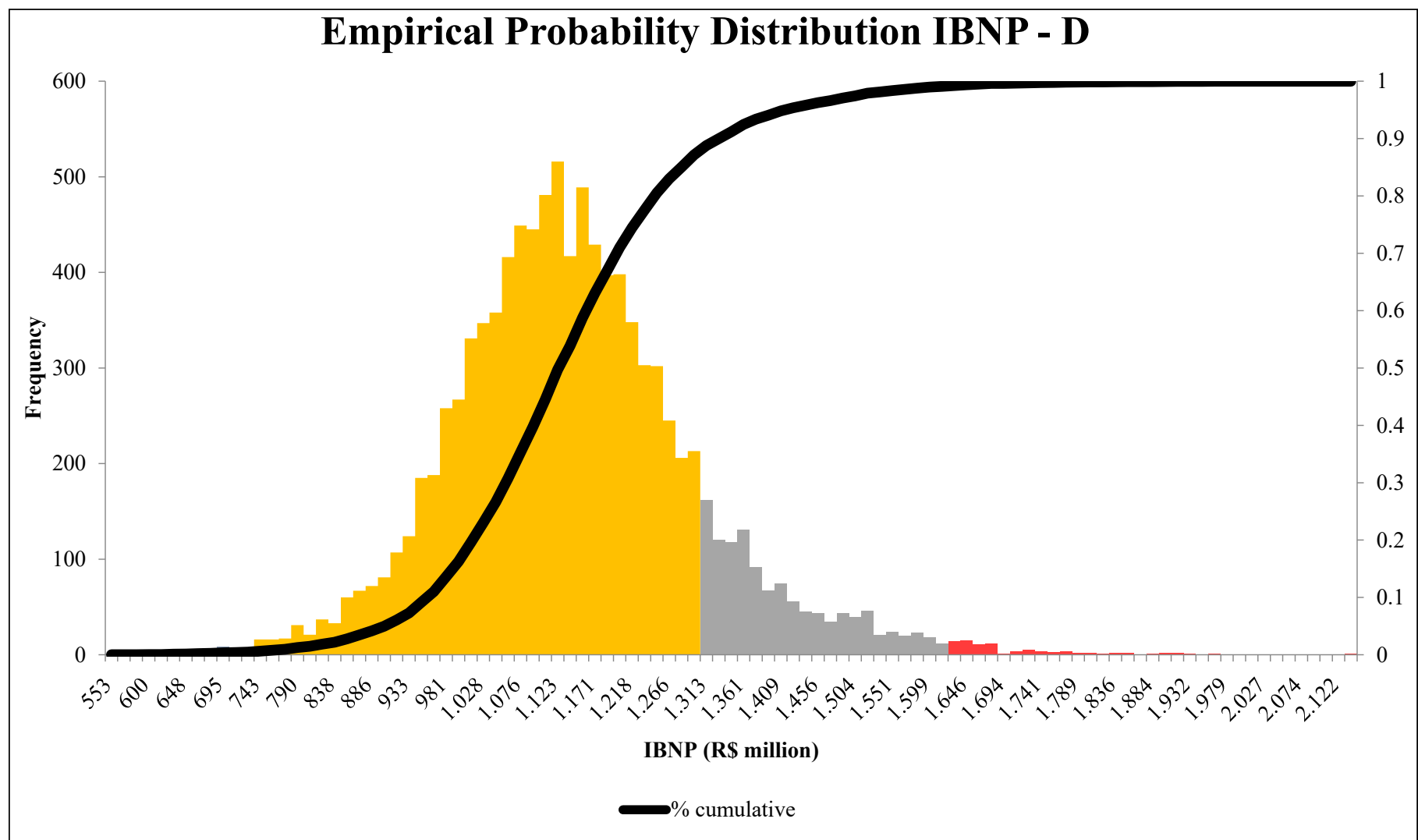

Figure 9. Empirical probability distribution of IBNP estimated by bootstrap — Insurer D. Source: Prepared by the authors.

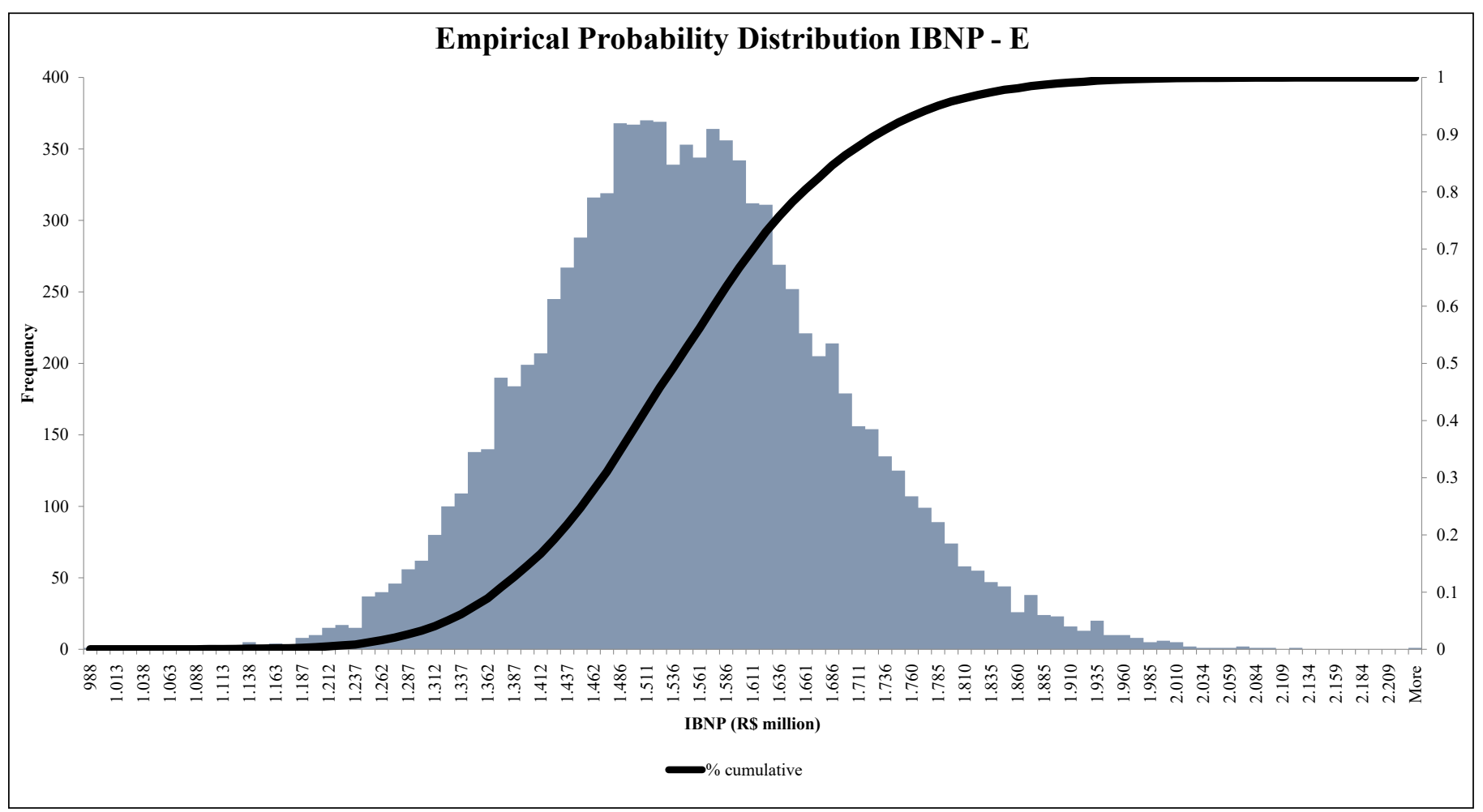

Figure 10. Empirical probability distribution of IBNP estimated by bootstrap — Insurer E. Source: Prepared by the authors. 
Therefore, for the studied sample, through the England and Verrall's (1999) model applied, it is possible to estimate a sufficiency level of the technical provisions.

However, it is imperative to clarify the limitations of the findings. Considering that the data from the explanatory notes bring together several portfolios of different insurance products, the analysis becomes limited by the non-granularity of the information, so that different products have different underwriting profiles. Additionally, the model on screen fails to adequately capture the introduction of new products, the sale of portfolios, and the eventual termination of partnership contracts and the presence of outlier claims, elements that can substantially affect the development of the triangles of paid claims and consequently the estimates made by the bootstrap method. In this context, the analysis model suggested by the work does not replace, under any circumstances, the LAT and any insufficiencies measured in the PCC, nor does it constitute a criticism of the work of the management, the actuaries of the companies, or the external auditors (the latter, in fact, have detailed information to assess more accurately the level of insufficiency of provisions), being, therefore, a proposal for a methodology for external analysts who do not have the information in its greatest granularity.

Finally, it appears that given the lack of standardization of disclosure criteria, the comparison between insurers is impaired. For instance, the study sample was limited to five cases. Even so, it was possible to verify a great variability in the findings, demonstrating how underwriting risk management varies from company to company.

\section{CONCLUSION}

This work started from the following question:

Is it possible to infer about the sufficiency of provisions in the balance sheet of Brazilian insurers, through the financial statements of those entities?

It was verified, through empirical effort, that the lack of uniformity in the criteria for disclosing information regarding the development of claims hinders the applicability of empirical models that allow such estimation. Additionally, the lack of standardization also leads to problems in comparing the economic, financial, and equity situation of insurers. However, standardization does not necessarily lead to a higher quality of information disclosed, given that insurers are not necessarily directly comparable. As noted above, different insurance products have different risk development characteristics. Therefore, the creation of a single pattern tends not to capture the specificities associated with each portfolio at different moments. Nevertheless, the creation of an accounting information disclosure standard must consider the criteria of relevance and materiality, as indicated by CPC 00 (R2) (Comitê de Pronunciamentos Contábeis [CPC], 2019). Therefore, the marginal benefits associated with the information to be produced and disclosed must outweigh the respective marginal costs, which requires a careful analysis by the entity that prepares the financial statements.

Thirty-one insurers were selected for the analysis, and they represented more than $90 \%$ of the written premiums in the Brazilian market in 2019 for non-life insurance. After checking for different disclosure patterns, five insurers were selected in this sample, which adopted similar disclosure procedures and that allowed the application of the England and Verrall (1999) model to estimate the probability distribution function associated with the IBNP.

The results revealed that there is evidence of earnings management by insurers regarding the uncertainty associated with technical provisions. However, it is essential to emphasize again that the adopted model fails to adequately capture the introduction of new products, the sale of portfolios, and the eventual termination of partnership contracts and the presence of outlier claims, elements that can substantially affect the development of paid claims triangles and consequently the estimates made by the bootstrap method.

Therefore, the work can be seen as a proposal for a methodology for analyzing the uncertainty of provisions that can be applied by external users who do not have access to the data in its greatest granularity, as long as they are aware of the associated limitations.

\section{NOTES}

1. It is essential to understand that incurred claims can be defined as the sum of claims paid and claims reported but not settled.

2. The chain ladder method applied to the incurred claims method will not be addressed in this work, despite its similarity with the latter.

3. According to Art. $2^{\circ}$ of Resolution CNSP No. 321, of 2015, item V, the adjusted surplus is the "book equity or accounting equity, as the case may be, adjusted by additions and exclusions, to determine, more qualitatively and strictly, the available resources that enable the supervised bodies to carry out their activities in the face of fluctuations and adverse situations, and must be net of assets with a high level of valuation subjectivity or that already guarantee similar financial activities, and other assets whose nature is considered by the body regulator as inappropriate to safeguard its solvency" (our translation).

4. CNSP Resolution No. 321, of 2015, better explains the calculation criteria for both base capital and risk capital that insurance companies must follow in Brazil. 


\section{REFERENCES}

Actuarial Standards Board. (2011a). Actuarial Standard of Practice No. 36. Retrieved from http://www.actuarialstandardsboard. org/wp-content/uploads/2014/06/asop36 secondrevision.pdf

Actuarial Standards Board. (2011b). Actuarial Standard of Practice No. 43. Retrieved from http://actuarialstandardsboard. org/wp-content/uploads/2014/07/asop043 106.pdf

Albarrán, I. L., \& Alonso, P. G. (2011). Métodos etocásticos de estimación de las provisiones técnicas en el Marco de Solvencia II. Madrid, ES: Fundación Mapfre.

Altieri, E., Fraga, E., \& Veiga, A. (2014). Modelo de cálculo da necessidade de capital para cobrir os riscos de subscrição de operaçôes não vida. Revista Brasileira de Risco e Seguro, 9(17), 1-46. Retrieved from https://www.rbrs.com.br/arquivos/rbrs $17 \quad 1 . \mathrm{pdf}$

Al-Yatama, S. K., Ali, M. S., Awadhi, K. M., \& Shamali, N. M. (2020). The effects of credit risk, operational risk and liquidity risk on the financial performance of insurance companies listed at kuwait stock exchange. European Journal of Economic and Financial Research, 3(6), 1-9. https://doi.org/10.5281/zenodo.3605377

Anker, R. A. (1973). Loss Reserving Methods. Proceedings of the Casualty Actuarial Society. Retrieved from https://www.casact.org/pubs/proceed/proceed73/73059.pdf

Balona, C., \& Richman, R. (2020). The actuary and IBNR techniques: a machine learning. SSRN. http://dx.doi.org/10.2139/ssrn.3697256

Badounas, I. \& Pitselis, G. (2020). Loss reserving estimation with correlated run-off triangles in a quantile longitudinal model. Risks, 8(1), 181-195. https://doi.org/10.3390/risks8010014

Berrar, D. (2019). Introduction to the Non-Parametric Bootstrap. Encyclopedia of Bioinformatics and Computational Biology, 766-773. https://doi.org/10.1016/B978-0-12-809633-8

Berry-Stölzle, T. R., Eastman, E. M., \& Xu, J. (2018). CEO Overconfidence and Earnings Management: Evidence from Property-Liability Insurers Loss Reserves. North American Actuarial Journal, 22(3), 380-404. https://doi.org/10.1080/10920277.2017.1421977

Bornhuetter, R. L., \& Ferguson, R. E. (1972). The Actuary and IBNR. Proceedings of the Casualty Actuarial Society, 59, 181-195. Retrieved from https:/www.casact.org/pubs/proceed/proceed72/72181.pdf

Caldas, G., Curvello, R., \& Rodrigues, A. (2016). Contabilidade dos Contratos de Seguro. Rio de Janeiro: ENS. Retrieved from https://www.ens.edu.br/arquivos/ contabilidadedoscontratosdeseguro.pdf

Carvalho, B. D., \& Carvalho, J. V. (2019). Umaabordagem estocástica para a mensuração da incerteza das provisôes técnicas de sinistros. Revista Contabilidade \& Finanças, 30(81), 409424. https://doi.org/10.1590/1808-057×201907860

Casualty Actuarial Society. (2014). Statement of principles regarding property and casualty unpaid claims estimates. Retrieved from https://www.casact.org/sites/default/files/2021-04/ Statement of Principles_Regarding_Property_and Casualty_Unpaid_Claims_Estimates_2021.pdf
Chase, T. R. (2015). Analysis of Bootstrap Techniques for Loss Reserving. (thesis). Fargo, North Dakota: North Dakota State University of Agriculture and Applied Science. Retrieved from https://library.ndsu.edu/ir/bitstream/ handle/10365/27842/Analysis\%20of\%20Bootstrap $\% 20$ Techniques \% 20 for \% 20 Loss \% 20 Reserving. pdf?sequence $=1$ \&isAllowed $=y$

Christiansen, M., \& Niemeyer, A. (2014). Fundamental Definition of the Solvency Capital Requirement in Solvency II. ASTIN Bulletin, 44(3), 501-533. http://dx.doi.org/10.1017/asb.2014.10

Comitê de Pronunciamentos Contábeis. (2019). CPC OO (R2) Estrutura conceitual para relatório financeiro. Retrieved from http://static.cpc.aatb.com.br/Documentos/573 CPC00(R2).pdf

Comitê de Pronunciamentos Contábeis. (2008). CPC 11 Correlação às Normas Internacionais de Contabilidade - IFRS 4. Retrieved from http://static.cpc.aatb.com.br/ Documentos/215 CPC 11 rev\%2003.pdf

Comitê de Pronunciamentos Contábeis. (2009). CPC 25 Provisóes, passivos contingentes e ativos contingentes. Comitê de Pronunciamentos Contábeis. Retrieved from http:// www.cvm.gov.br/export/sites/cvm/menu/regulados/ normascontabeis/cpc/CPC 25 rev 12.pdf

Conselho Nacional de Seguros Privados (2015). Resolução CNSP No 321. Retrieved from https://www2.susep.gov.br/safe/ scripts/bnweb/bnmapi.exe? router=upload/24251

Costa, J. F., \& Yui, L. M. (2018). Comparação de Métodos de Cálculo de Ibnr para uma operadora de planos de saúde através do método de análise hierárquica. Cadernos do IME - Série Estatística, 44, 19-36. https://doi.org/10.12957/cadest.2018.38491

Council of the European Union (2009). Directive 2009/138/EC. Retrieved from https://eur-lex.europa.eu/LexUriServ/ LexUriServ.do?uri=OJ:L:2009:335:0001:0155:EN:PDF

Das, S. C. (2013). Corporate social reporting and human resource disclosures: Experiences from insurance companies in India. Social Responsibility Journal, 9(1), 19-32. https://doi.org/10.1108/17471111311307796

England, P., \& Verral, R. (2002). Stochastic claims reserving in general insurance. British Actuarial Journal, 8(3), 443518. https://doi.org/10.1016/S0167-6687(99)00016-5

England, P., \& Verrall, R. (1999). Analytic and bootstrap estimates of prediction errors in claims reserving. Insurance: Mathematics and Economics, 25(3), 281-293. https://doi.org/10.1016/S0167-6687(99)00016-5

Friedland, J. (2010). Estimating Unpaid Claims Using Basic Techniques. Casualty Actuarial Society. Retrieved from https://www.casact.org/library/studynotes/Friedland estimating.pdf

Gabrielli, A. (2019). A neural network boosted double over-dispersed poisson claims reserving model. SSRN Electronic Journal, 50(1), 25-60. https://doi.org/10.1017/asb.2019.33

Hemrit, W., \&Arab, B.M.(2011). The disclosure of operational riskin Tunisian insurance companies. Journal of Operational Risk, 6(2), 69-111. https://doi.org/10.21314/JOP.2011.089 
Höring, D., \& Gründl, H. (2011). Investigating risk disclosure practices in the European insurance industry. The Geneva Papers, 36(3), 380-413. http://dx.doi.org/10.2139/ssrn.1803114

Hsu, W., Huang, Y. R., \& Lai, G. (2019). Reserve Management and Audit Committee Characteristics: Evidence from U.S. Property-Liability Insurance Companies. The Journal of Risk and Insurance, 86(4), 1019-1043. https://doi.org/10.1111/jori.12251

Jackson, R. H., \& Wood, A. (2013). The performance of insolvency prediction and credit risk models in the UK: A comparative study. The British Accounting Review, 45(3), 183-202. https://doi.org/10.1016/j.bar.2013.06.009

Lemaire, J. (1985). Automobile Insurance: Actuarial Models. ASTIN Bulletin, 16(2), 186-187. https://doi.org/10.1017/S0515036100005523

Lindholm, M., Verrall, R., Wahl, F., \& Zakrisson, H. (2020). Machine learning, regression models, and prediction of claims reserves. Casualty Actuarial Society E-Forum. Retrieved from https://www.casact.org/sites/default/files/ presentation/cs22-reservescallpapers-fileid-254915.pdf

Lock, I., \& Seele, P., (2015). Quantitative content analysis as a method for business ethics research. Business Ethics: A European Review, 24(S1), S24-S40. https://doi.org/10.1111/beer.12095

Lopez, O., \& Milhaud, X. (2020). Individual reserving and nonparametric estimation of claim amounts subject to large reporting delays. Scandinavian Actuarial Journal, 2021(1), 1-20. https://doi.org/10.1080/03461238.2020.1793218

Mack, T. (1993). Distribution-free calculation of the standard error of chain ladder reserve estimates. ASTIN Bulletin, 23(2), 213-225. https://doi.org/10.2143/AST.23.2.2005092

Malafronte, I., Starita, M. G., \& Porzio, C. (2016). The nature and determinants of disclosure practices in the insurance industry: Evidence from European insurers. International Review of Financial Analysis, 45, 367-382. https://doi.org/10.1016/j.irfa.2015.02.003

Mano, C. C., \& Ferreira, P. P. (2009). Aspectos atuariais e contábeis das provisóes técnicas. Rio de Janeiro, RJ: ENS. Retrieved from https://www.ens.edu.br/publicacoes-detalhes/119

McClenahan, C. L. (2003). Estimation and application of ranges of reasonable estimates. Proceeding of Casualty Actuarial Society Forum, 60. pp. 213-230. Retrieved from https://www.casact.org/pubs/forum/03fforum/03ff213.pdf

Mendes, A., Cardoso, R. L., Mário, P. C., Martinez, A. L., \& Ferreira, F. R. (2014). Insolvency prediction in the presence of data inconsistencies. Intelligent System in Accounting, Finance and Management, 21(3), 155-167. https://doi.org/10.1002/isaf.1352

Ramos-Pérez, E., Alonso-González, P. J., \& Nuñez-Velazquez, J. J. (2020). Stochastic reserving with a stacked model based on a hybridized Artificial Neural Network. Expert Systems with Applications, 163. https://doi.org/10.1016/j.eswa.2020.113782
Schmidt, K. D. (2006). Methods and models of loss reserving based on run-off triangles: A unifying survey. Proceedings of Casualty Actuarial Society Forum, pp. 269-317. Retrieved from https://www.casact.org/pubs/forum/06fforum/273.pdf

Skurnick, D. (1973). A survey of loss reserving methods. Proceedings of the Casualty Actuarial Society. Retrieved from https://www.casact.org/pubs/proceed/proceed73/73016.pdf

Sriram, K., \& Shi, P. (2020). Stochastic loss reserving: A new perspective from a Dirichlet model. The Journal of Risk and Insurance. https://doi.org/10.1111/jori.12311

Superintendência de Seguros Privados. (2015). Circular Susep no 517. Diário Oficial da União. Brasília, DF: Exército Brasileiro. Retrieved from https:// pesquisa.in.gov.br/imprensa/jsp/visualiza/index. jsp?.jornal $=1 \&$ data $=11 / 08 / 2015 \&$ pagina $=19$

Sürdü, F. B., Çalışkan, A. Ö., \& Emel, E. (2020). Human resource disclosures in corporate annual reports of insurance companies: A case of developing country. Sustainability, 12(8), 3452. https://doi.org/10.3390/su12083452

Taylor, G. C., \& Ashe, F. R. (1983). Second moments of estimates of outstanding claims. Journal of Econometrics, 23(1), 3761. https://doi.org/10.1016/0304-4076(83)90074-X

Ullah, M. S., Muttakin, M. B., \& Khan , A. (2019). Corporate governance and corporate social responsibility disclosures in insurance companies. International Journal of Accounting \& Information Management, 27(2), 284-300. http://dx.doi.org/10.1108/IJAIM-10-2017-0120

Veras, B. S. (2016). Evidenciação de contratos de seguros e passivo atuarial em seguradoras brasileiras para a data base de 31 de Dezembro de 2015 (trabalho de conclusão de curso). Brasília, DF: Universidade de Brasília. Retrieved from https://bdm.unb.br/handle/10483/16140

Verrecchia, R. E. (2001). Essays on disclosure. Journal of Accounting and Economics, 32(1-3), 97-180. https://doi.org/10.1016/S0165-4101(01)00025-8

Vieira, D. M. (2016). Provisão de sinistros processo de análise $e$ tomada de decisão (dissertação). São Paulo, SP: Pontífica Universidade Católica. Retrieved from http://bdtd.ibict.br/vufind/Record/PUC SP-1 fb7dc1aaf963994ecadc59a6c413df4e/Description

Wang, Z. (2020). Analysis of insurance companies performance capital structure and soundness: Evidence from the United Kingdom. Market (tese). Falmer, East Sussex, UK: University ofSussex. Retrieved from http://sro.sussex.ac.uk/id/eprint/92209/

Yuassa, V. S. (2018). Análise técnica das provisóes de técnicas e teste de adequação dos passivos para seguradoras (dissertação). São Paulo, SP: Pontífica Universidade Católica. Retrieved from http://bdtd.ibict.br/vufind/Record/PUC SP-1 5de 656807b003e61df54bd8efee0d429 


\section{Authorship}

\section{Roberto Bomgiovani Cazzari*}

Universidade Federal de Sáo Paulo, Escola Paulista de Política, Economia e Negócios

Rua Oleska Winogradow, n. 100, Jardim das Flores, 06120-042, Osasco, SP, Brazil

E-mail: roberto.cazzari@unifesp.br

(1) https://orcid.org/0000-0001-8751-0203

\section{Guilherme Rodovalho Fernandes Moreira}

Universidade Federal de São Paulo, Escola Paulista de Política, Economia e Negócios

Rua Oleska Winogradow, n. 100, Jardim das Flores, 06120-042, Osasco, SP, Brazil

E-mail: grfm06@gmail.com

(1) https://orcid.org/0000-0002-1476-0954

* Corresponding Author

\section{Funding}

The authors reported that there is no financial support for the research in this article.

\section{Conflict of Interests}

The authors have stated that there is no conflict of interest.

\section{Copyrights}

RAC owns the copyright to this content.

\section{Peer Review Method}

This content was evaluated using the double-blind peer review process. The disclosure of the reviewers' information on the first page, as well as the Peer Review Report, is made only after concluding the evaluation process, and with the voluntary consent of the respective reviewers and authors.

\section{Authors' Contributions}

$1^{\text {st }}$ author: conceptualization (equal); data curation (equal); formal analysis (equal); funding acquisition (equal); investigation (equal); methodology (equal); project administration (equal); resources (equal); software (equal); supervision (equal); validation (equal); visualization (equal); writing-original draft (equal); writing-review \& editing (equal).

$2^{\text {nd }}$ author: conceptualization (equal); data curation (equal); formalanalysis (equal); fundingacquisition (equal); investigation (equal); methodology (equal); project administration (equal); resources (equal); software (equal); supervision (equal); validation (equal); visualization (equal); writing-original draft (equal); writing-review $\&$ editing (equal).

\section{Plagiarism Check}

The RAC maintains the practice of submitting all documents approved for publication to the plagiarism check, using specific tools, e.g.: iThenticate.

\section{Data Availability}

The authors claim that all data and materials have been made publicly available through the Harvard Dataverse platform and can be accessed at:

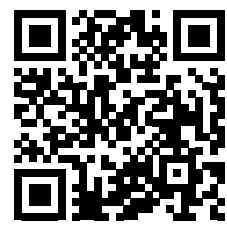

Cazzari, Roberto Bomgiovani; Moreira, Guilherme Rodovalho Fernandes, 2021, "Replication Data for: "Uncertainty of Claims Provisions from the Analysis of Financial Statements" published by RAC-Revista de Administração Contemporânea", Harvard Dataverse, V1. https://doi.org/10.7910/DVN/OSMMTJ

RAC encourages data sharing but, in compliance with ethical principles, it does not demand the disclosure of any means of identifying research subjects, preserving the privacy of research subjects. The practice of open data is to enable the reproducibility of results, and to ensure the unrestricted transparency of the results of the published research, without requiring the identity of research subjects. 